\title{
Synthesis of Ca-Psz nanoparticles using sol-gel technique with chitosan as a dispersant for raw materials restoration and dental rehabilitation equipment
}

\author{
Fadilla Rizky Prameshwari*, Elin Karlina*, Zulia Hasratiningsih* \\ 'Department of Dental Materials Science and Technology Faculty of Dentistry \\ Universitas Padjadjaran
}

\begin{abstract}
Introduction: Zirconia $\left(\mathrm{ZrO}_{2}\right)$ is a metal-free substance that rapidly improving as dental materials that has a good properties which are high biocompatibility, esthetics, and strength. Addition of a stabilizer like $\mathrm{CaO}$ will increase the mechanical properties of zirconia due to the transformation toughening. Methods: The Calcia Partially Stabilized Zirconia (Ca-PSZ) nanoparticles can be synthesized by using sol gel technique. This method makes easier to control the purity, homogeneity and physical characteristics at low temperature. This method consists of two stages, hydrolysis and condensation. The precursor were used Zirconium Chloride $\left(\mathrm{ZrCl}_{4}\right)$ with $0,1 \mathrm{M}$ concentration and Calcia as stabilizer with $7 \%$ concentration. The addition of Calcia will help the tetragonal crystals forming at low temperature. Calcination temperature was used $900^{\circ} \mathrm{C}$. To prevent conglomeration or agglomeration, dispersants are needed. One of the dispersants available is chitosan. Results: X-Ray Diffraction (XRD) analysis identifies that there are tetragonal and monoclinic phase with a percentage of $85 \%$ and $15 \%$ perspectively for sample without using chitosan and $100 \%$ tetragonal for sample that using chitosan. Analysis of Scanning Electron Microscope (SEM) results that particles with chitosan are more homogenous and dispersed with smaller size produced compared to particles without chitosan. Conclusion: From the results of the analysis, Ca-PSZ with sol-gel technique can produce nanoparticle and addition of chitosan can dispersed nanoparticles that could be used as material restoration and rehabilitation component in dentistry.
\end{abstract}

Keywords : Ca-PSZ, Nanoparticles, Chitosan, Dispersant, Sol Gel

\section{INTRODUCTION}

Ceramic material specially developed for medical and dental purposes is called bioceramics. One example of bioceramics is zirconia. Over the past decades, zirconia technology has developed rapidly as a metal-free dental material that has high biocompatibility, aesthetic value, and strength. 1,2,3 Excellent molecular stability can be achieved by combining zirconia crystals with alkali metal oxides such as $\mathrm{MgO}, \mathrm{CaO}$, or $\mathrm{Y} 2 \mathrm{O} 3$ as a stabilizer. The addition of this stabilizer has a role during the process of transformation toughening works to prevent cracking so that the zirconia crystals becomes stronger. The addition of zirconia with alkali metal oxides is called Partially

Corresponding author: Elin Karlina, Department of Dental Materials Science and Technology, Faculty of Dentistry Universitas Padjadjaran, Indonesia. Jalan Sekeloa Selatan I, Bandung, West Java, Indonesia, 40132; Phone: +6222-2504985/2532805 
Stabilized Zirconia (PSZ). ${ }^{2,3,4,5}$ The use of PSZ very much begins from the fields of industry, medicine, and dentistry. Since 1990, this form of PSZ has been introduced as a dental material because of its excellent strength and good fracture resistance. PSZ gained popularity in many industries because of its high resistance, fracture strength (7-8MP), flexure strength $(0.9-1.5 \mathrm{GPa})$, corrosion resistance and good thermal conductivity. ${ }^{3,5}$

In dentistry, the use of PSZ is as a composite filler, crown and bridge, orthodontic bracket, and implant. Research on PSZ in Dentistry is often carried out in the prosthodontics field as a crown and bridge to replace porcelain fused metal (PFD) and framework. ${ }^{2,5,6}$

Metal oxide stabilizers such as $\mathrm{MgO}$ and Y2O3 have deficiencies, including MgO not very well used in dentistry as it produces large porosity and granular shape $(30-60 \mu \mathrm{m})$ which influences auxin resistance1. (Denry and Kelly, 2007) While Y2O3 is a rare and expensive material. Both metal oxides also have more toxic properties than $\mathrm{CaO}$. $\mathrm{CaO}$, a metal oxide that has the advantage over other stabilizers because it is similar to boneforming material7 (Shtansky, 2003) and thus is more biocompatible. $\mathrm{CaO}$ is also cheaper and easier to obtain. This $\mathrm{CaO}$ stabilizer can also prevent cracking on its crystal structure. ${ }^{3,4}$

There are various ways of making PSZ; in this study, the sol-gel technique was chosen. This technique is commonly used in metal oxides and its advantages can facilitate the control of purity, homogeneity, and physical characteristics at low temperatures. This technique can also be used to design microstructures so that particle size can be adjusted..$^{8,9,10}$ In the manufacture of PSZ particles can be agglomerated. Prevention

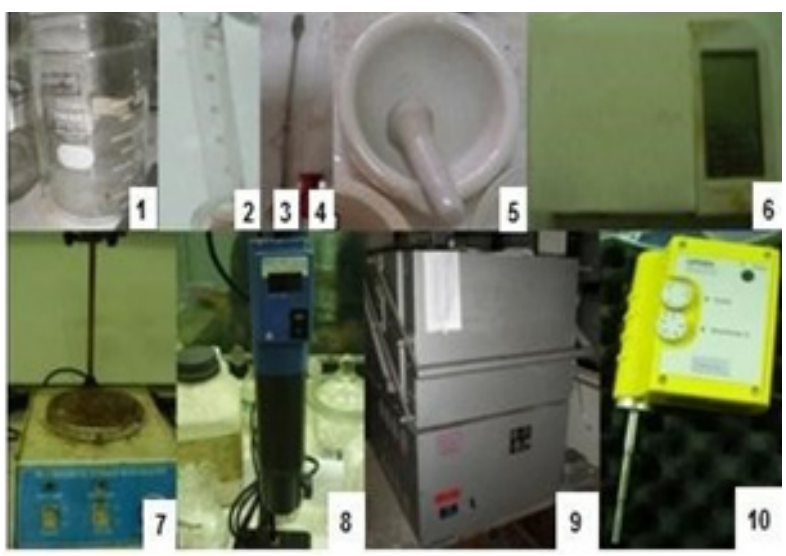

needed are dispersants, one of which is chitosan. Chitosan is an ingredient derived from natural ingredients such as shrimp shells containing chitin. Chitosan is used so that particles can be well dispersed or agglomeration does not occur because chitosan makes a particle does not stick to other particles. ${ }^{10,11,12}$

Based on the explanation above, the author is interested in researching the manufacture of Partially Stabilized Zirconia based on restorative materials to obtain nanometer particle sizes from Ca-PSZ by using sol-gel and chitosan techniques as dispersing agents. The results of this synthesis will be characterized by using X-ray Diffraction (XRD) to see the zirconia crystal phase and Scanning Electron Microscope (SEM) to see the morphology and microstructure including the size of zirconia particles synthesized.

\section{METHODS}

The type of research is a quasi-experimental study with qualitative and quantitative analysis with the Partially Stabilized Zirconia (PSZ) nanoparticles and observation of the sample characteristics using X-Ray Diffraction (XRD) and Scanning Electron Microscope (SEM). The samples used in this study were two nanoparticle specimens consisting of powder-formed Ca-PSZ with the addition of $1 \%$ chitosan, powder-formed Ca-PSZ without the addition of $1 \%$ chitosan.

Figure 1. Tools used in the making of CaPSZ nanoparticles, (1) $250 \mathrm{ml}$ chemical beakers, (2) $250 \mathrm{ml}$ measuring cups, (3) spatulas, (4) pipettes, (5) mortars and pestles, (6) digital scales (Mini Pocket Scale MA 100A sensitivity 0.01 g), (7) Magnetic stirrer, (8) Ultra turra stirrer (IKA

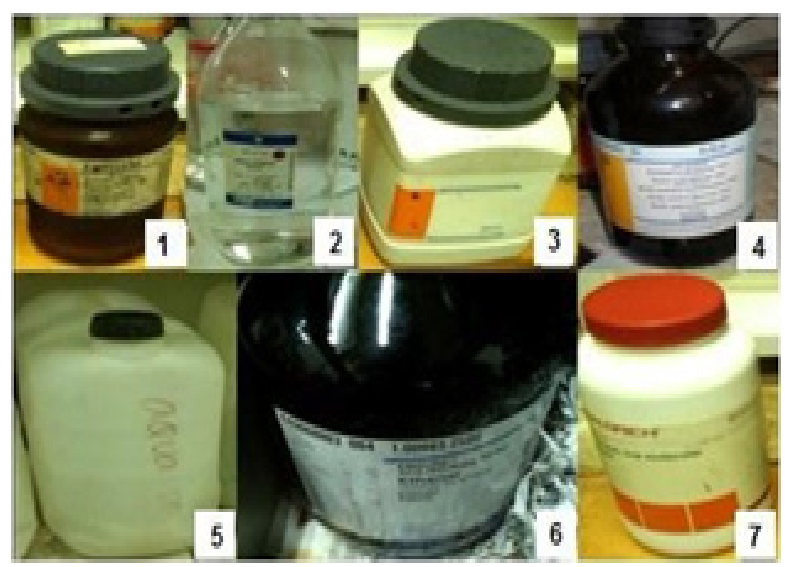


T25 Digital Ultaraturrax max. $24000 \mathrm{rpm})$, (9) Furnaces, (10) Ultrasonic Homogenizer (UP50H Hielscher max $12000 \mathrm{~Hz}$ ). Figure 2 Materials used in the preparation of Ca-PSZ nanoparticles,

(1) Zirconium Chloride ( $\mathrm{ZrCl} 4)$ as precursors, (2) Aquabides as solvents, (3) $\mathrm{Ca}$ (NO3) 2 as stabilizers, (4) Acetic acid as solvents, (5) Aqua Demineralized (Aqua DM) as a solvent, (6) Ethanol as a solvent, (7) Chitosan as a dispersant.

\section{RESULTS}

The data obtained is the result of the characterization using XRD and SEM. The data from this study were used to analyse the characteristics such as the crystal structure formed, size of the crystals, morphology and particle size of samples that have been synthesized by sol-gel technique. XRD characterization is useful to identify the phase or character of the sample made. From this result, we can determine whether the desired tetragonal phase is formed or not. The calcination temperature used in this study was $900^{\circ} \mathrm{C}$. The crystalline phase formed was determined by comparing the diffraction angle of the peak XRD results with the database of the X-Powder

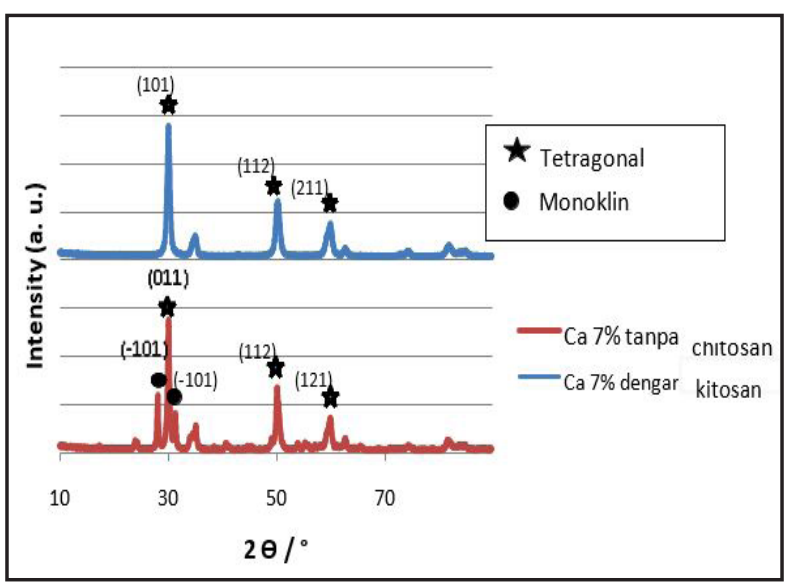

Figure 3 XRD diffractogram of Ca-PSZ nanoparticle samples using chitosan and without using chitosan

software. The X-powder used is Ver.2004.04.70. $P R O$ with tetragonal crystal reference number $=42$ 1464 and monoclinic $=37-1484$. Tetragonal phase nor monocline appears in the sample, as shown in figure 3. From Figure 3, it can be seen that there are differences in crystals formed in the sample using chitosan and without chitosan. In samples with chitosan, the tetragonal crystal structure at the peak of the highest diffraction angle $(2 \theta)$ was $30,095^{\circ}, 50,280^{\circ}$, and $60,025^{\circ}$. Samples without chitosan showed tetragonal crystals formed at a diffraction angle of $30.225^{\circ}, 50.140^{\circ}, 59.970^{\circ}$. The microstructure of the sample particles can be seen and observed using a Scanning Electron Microscope (SEM) tool. This tool is used to find the morphology and growth of particles that occur. With the calcination temperature used at $900^{\circ} \mathrm{C}$, an SEM image found in CaPSZ samples with the addition of chitosan and without chitosan, it can be seen in Figure 4. Ca-PSZ particles with chitosan are more homogeneous and dispersed compared to without the addition of chitosan.

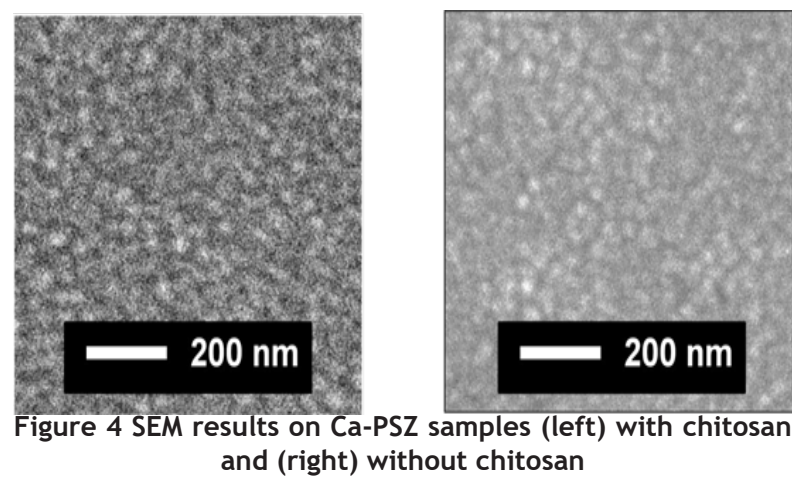

\section{DISCUSSION}

Synthesis of nanoparticles carried out in this study referred to previous studies (Hermawan, 2010). During the last research, nanoparticle synthesis using Y2O3 stabilizer with sol-gel technique.

The research was successful in synthesizing Y-PSZ nanoparticles, while in this study it was incorporated using the same method but with a different stabilizer, $\mathrm{CaO}$. In the process of making selected nanoparticles using the sol-gel method that includes stages that consist of hydrolysis and condensation.

The hydrolysis stage occurs when the precursor $(\mathrm{ZrCl} 4)$ reacts with aqua bides with the following reaction. $\mathrm{ZrCl} 4+4 \mathrm{H} 2 \mathrm{O} \mathrm{Zr}(\mathrm{OH}) 4+$ $4 \mathrm{HCl}$ At this stage of hydrolysis, there is a break of $\mathrm{ZrCl} 4$ metal bonds by water to form metal hydroxide compounds, called $\mathrm{Zr}(\mathrm{OH}) 4$. The result of the hydrolysis reaction is $\mathrm{HCl}$, which is a weak acid with a $\mathrm{pH}=2$. Colloid sol $\mathrm{Zr}(\mathrm{OH}) 4$ occurs when the $\mathrm{pH}$ must be at 2 to 3 as shown. The area that is not shaded is when the solution occurs. The 
line between the two regions shows when colloids occur. For $\mathrm{Zr}(\mathrm{OH}) 4$, if the $\mathrm{pH}$ is less than 2 (white area), then a solution is formed; If the solution is formed, the condensation reaction occurs very slowly. However, if the $\mathrm{pH}$ is more than 3 , the condensation reaction will occur more quickly, and larger particles are formed. ${ }^{10}$

The addition of $\mathrm{CaO}$ affects the mechanical properties of zircons. Without the addition of $\mathrm{CaO}$ or stabilizer zirconia will have a low mechanical property and can quickly turn into a monocline crystal phase at room temperature. This addition of $\mathrm{CaO}$ helps zirconia to have a tetragonal crystal phase at room temperature and has high strength. Chitosan acts as a surfactant that acts as a zirconia particle wrapper in the stage before calcination is carried out. Chitosan dissolved in acetic acid makes chitosan to have an amino group $(\mathrm{NH} 2)$ and will be cationic (affirmative).

$\mathrm{ZrCl} 4$ hydrolysis reaction results in the form of $\mathrm{Zr}(\mathrm{OH}) 4$ which are anion (negative), due to the $\mathrm{OH}$-group. When chitosan is added, the surface of the negatively charged particles will be immediately covered by positively charged chitosan. The surface of the particles that are covered with chitosan will cause the growth of the particles to stop. The result is particles that have become smaller in size. The effect of the addition of chitosan will also cover the surface of the particles and prevent contact with other particles, thereby preventing agglomeration.

The particles formed will be more homogeneous and well dispersed. Therefore chitosan in this research is called dispersant.

Figure 3 shows the differences in the structure of the crystalline phase formed in the Ca-PSZ sample. In samples with the addition of chitosan, visible aspects formed purely tetragonal. In the x-powder software, the percentage of the tetragonal crystalline phase is $100 \%$. Thus, it proves that the sample has a single tetragonal crystal. Samples without chitosan observed as the tetragonal crystal and monocline crystal. This monocline crystal appears with the name baddeleyite.

The percentage of $x$-powder showed a tetragonal phase of $85 \%$ and a monoclinic crystal phase of $15 \%$. So samples without chitosan have a multi-phase, namely monoclinic and tetragonal phases. The effect of chitosan will make the $\mathrm{Ca}$ -
PSZ particles dispersed, thus helping the $\mathrm{CaO}$ stabilizer work optimally; therefore; as a result, it forms a tetragonal crystal. Samples without chitosan allow agglomeration to inhibit the formation of crystals; thus, $\mathrm{CaO}$ stabilizers do not work optimally; as a result, it forms tetragonal and monocline crystals.

Previous studies have shown there is an effect of calcination temperature in the formation of the crystalline phase. The results of the survey stated that Ca-PSZ calcined at temperatures of $600^{\circ} \mathrm{C}, 800^{\circ} \mathrm{C}$ and $1000^{\circ} \mathrm{C}$ only formed the cubic phase and at temperatures of $1300^{\circ} \mathrm{C}, 1400^{\circ} \mathrm{C}$, and $1500^{\circ} \mathrm{C}$ formed tetragonal and monoclinic phases. ${ }^{13}$ From Figure 2.7 about the $\mathrm{ZrO2}-\mathrm{CaO}$ equilibrium phase, it is also seen that the addition of temperature and composition affects the crystalline phase formed.

The size of the crystals in the chitosan sample is smaller than $15 \mathrm{~nm}$, while the example without chitosan is $20 \mathrm{~nm}$. The size of the glasses with chitosan is shorter because the nature of chitosan when encapsulating particles makes the voltage between particles decrease.

Figure 4 shows the differences in the results of characterization with SEM in the Ca-PSZ nanoparticle samples with the addition of chitosan and without the addition of chitosan. Particle size can be calculated from SEM images with 100,000x magnification. However, calculations using SEM images are not very accurate because the image quality is not very clear.

Particle size calculation can be done with SEM results. The scale comparison at $100,000 x$ magnification used to determine that the particle size is $0.1 \mu \mathrm{m}$. Particle size calculation is done by drawing a diagonal line in the SEM image and obtained a diagonal line length of $160 \mathrm{~mm}$, then counted the number of particles along the line obtained as many as 44 particles.

After the results are received, the length of the diagonal line is divided by the number of particles obtained. Then the average particle size in the image is $3.64 \mathrm{~mm}$. Furthermore, the average quantity of the particles is adjusted to a scale of $0.1 \mu \mathrm{m}$, while $0.1 \mu \mathrm{m}=100 \mathrm{~nm}=10 \mathrm{~mm}$. Then the average particle size in the sample is $36.4 \mathrm{~nm}$. In samples, without chitosan, the particle size is calculated in the same way through SEM images. A 100,000x magnification scale comparison is used 
to find out the particle size of $0.1 \mu \mathrm{m}$. Particle size calculation is done by drawing a diagonal line on the SEM image; the length of the diagonal line is $160 \mathrm{~mm}$. The number of particles along the path is calculated as many as 38 particles.

After the results are obtained, the length of the diagonal line is divided by the number of particles obtained. Then the average particle size in the image is $4.21 \mathrm{~mm}$. Furthermore, the average quantity of the particles is adjusted to a scale of $0.1 \mu \mathrm{m}$, while $0.1 \mu \mathrm{m}=100 \mathrm{~nm}=10 \mathrm{~mm}$.

Then the average particle size in the sample is $42.1 \mathrm{~nm}$. From the results of the above calculation, the particle size of Ca-PSZ with chitosan is smaller than Ca-PSZ without chitosan. Ca-PSZ particles with chitosan appear more homogeneous and dispersible compared to without the addition of chitosan.

\section{CONCLUSION}

Based on the results from the research conducted, it can be finalized that Ca-PSZ nanoparticles can be synthesized by sol-gel technique and the addition of chitosan influences the dispersion of nanoparticles formed with a single tetragonal structure.

\section{REFERENCES}

1. Pinkham, J.R. and P.S. Casamassimo; et al., 2005. Pediatric Dentistry: Infancy Through Adolescence. 4th ed. St. Louis: Elsevier Saunders.p. 463-476.

2. Soetjingsih. Tumbuh Kembang Anak . Jakarta : EGC. 1995. p. 127.

3. Lamid A. Pengaruh Docosahexaenoic Acid (DHA) pada tumbuh kembang anak balita gizi buruk yang dirawat jalan. J. Teknol dan Industri Pangan Vol XIII No.3. 2002. p. 234238.

4. Suwondo S. Pengantar Kuliah IImu Gizi Kedokteran. 2004. p. 53-54.

5. Marsetyo dan Kartasapoetra. IImu Gizi (Korelasi Gizi, Kesehatan dan Produktifitas
Kerja). Jakarta : Rineka Cipta. 2002. p. 56.

6. Sri. Gigi sehat dengan nutrisi. 2008.

7. Malina R. Normal weight gain in growing children. Health Weight Journal. 1999. 13(3)

8. Sudjana. 1996. Metode Statistika. 6th ed. Bandung: Tarsito. h. 6-7.

9. Gopalan, C. Nutrition Research in Southeast Asia. New Delhi: WHO. 2003 Available at: http://whqlibdoc.who.int/ publications/9290221666.pdf (diakses 28 Februari 2012).

10. Ferguson D. Oral Bioscience. London.: Chuchill Livingstone. 2003. p.4-16, 184-185.

11. Watanabe K. Effects of restricted calcium intake on bone and maxillofacial growth. Angle Orthodontist. 2008;78(3):445-452.

12. Almatsier S. Prinsip Dasar Ilmu Gizi. Jakarta : PT Gramedia Pustaka Utama. 2005. p. 230247.

13. Soetardjo S, Almatsier M, Soekarti. Gizi Seimbangan Dalam Daur Kehidupan. Jakarta: PT. Gramedia Pustaka Utama. 2011. p. 149157, 315-328.

14. Susiyanti. Calcium intake, attitudes toward calcium-containing food, and number of risk factors for osteoporosis in two groups of 18to 35-year-old women. 1996

15. Smolin LA, Grosvenor MB. Nutrition: Science and Application 4th ed. New York: Wiley. p. 92. 2003

16. Garrow JS, James WP. Human Nutrition and Dietetics. Edinburgh: Churchill Livingstone. 2000. p.37-59.

17. Mulyani, E. Konsumsi kalsium dan faktor faktor yang berhubungan dengan konsumsi kalsium pada remaja di SMP negeri 201 Jakarta Barat tahun 2009. 2009. Skripsi. Fakultas Kesehatan Masyarakat Universitas Indonesia.

18. Apriadji WH. Gizi Keluarga Seri Kesejahteraan Keluarga. Jakarta : PT Penebar Swadaya.h. 93. 1986

19. Soetardjo SS. Almatsier M. Soekarti. Gizi Seimbangan Dalam Daur Kehidupan. Jakarta: PT. Gramedia Pustaka Utama. 2011. p. 149157, 315-328. 